\title{
Update in the Management of ANCA-Associated Vasculitis: Recent Developments and Future Perspectives
}

\author{
Karla N. Samman $\mathbb{D}^{1},{ }^{2}$ Carolyn Ross $\mathbb{D}^{1},{ }^{1}$ Christian Pagnoux $\mathbb{D}^{2},{ }^{2}$ and Jean-Paul Makhzoum $\mathbb{D}^{1}$ \\ ${ }^{1}$ Vasculitis Clinic, Canadian Network for Research on Vasculitides (CanVasc), Division of Internal Medicine, Hôpital du Sacré-Coeur \\ de Montréal, University of Montreal, Montreal, Quebec, Canada \\ ${ }^{2}$ Vasculitis Clinic, Canadian Network for Research on Vasculitides (CanVasc), Division of Rheumatology, Mount Sinai Hospital, \\ University of Toronto, Toronto, Ontario, Canada
}

Correspondence should be addressed to Jean-Paul Makhzoum; jean-paul.makhzoum@umontreal.ca

Received 20 January 2021; Revised 26 March 2021; Accepted 29 March 2021; Published 8 April 2021

Academic Editor: Bruce M. Rothschild

Copyright (c) 2021 Karla N. Samman et al. This is an open access article distributed under the Creative Commons Attribution License, which permits unrestricted use, distribution, and reproduction in any medium, provided the original work is properly cited.

\begin{abstract}
Significant progress has been made in the treatment of ANCA-associated vasculitides (AAV), notably in granulomatosis with polyangiitis and microscopic polyangiitis. Over the past few years, many innovative studies have changed the way we now induce and maintain remission in AAV; achieving remission while limiting treatment toxicity is the key. This article provides an in-depth, up-to-date summary of recent trials and suggests treatment algorithms for induction and maintenance of remission based on the latest guidelines. Future possible therapies in AAV will also be discussed.
\end{abstract}

\section{Introduction}

Vasculitides are classified according to the size of vessels predominantly involved in the inflammatory process [1]. Antineutrophil cytoplasmic antibody- (ANCA-) associated vasculitides (AAV) are predominantly necrotizing, small vessel vasculitides and include granulomatosis with polyangiitis (GPA, previously known as Wegener's granulomatosis), microscopic polyangiitis (MPA), and eosinophilic granulomatosis with polyangiitis (EGPA, formerly Churg-Strauss syndrome) $[1,2]$. Serological markers include myeloperoxidase- (MPO-) ANCA and proteinase 3- (PR3-) ANCA, previously detected by immunofluorescence as perinuclear (p-ANCA) and cytoplasmic (c-ANCA), respectively [3-5].

Therapeutic advances in AAV have been substantial in the past 20 years. Before the use of high-dose glucocorticoids (GC) and cyclophosphamide (CYC), the mortality rate of patients with severe AAV was up to $80 \%$ one year after diagnosis [3]. Recent mortality rates decreased, and the estimated 5 -year survival is $74-91 \%$ and $45-76 \%$ for GPA and MPA, respectively [6]. Adequate medical management is crucial as patients with AAV remain at high risk of relapsing disease $[4,7]$. Infections associated with immunosuppressive therapy have become the leading cause of deaths during the first year of diagnosis of severe AAV, contributing to $34-48 \%$ of the mortality reported in some studies [3, 8].

This review presents the main clinical trials and advances in GPA and MPA that shaped today's induction and maintenance of remission therapeutic algorithms. This article provides an up-to-date summary of recent trials and suggests treatment algorithms for induction and maintenance of remission. The treatment of EGPA will not be discussed in this review. The present article does not replace guidelines issued by international and national vasculitis societies but is aimed at providing a pragmatic approach to the management of GPA and MPA.

\section{Classification of Disease Severity}

In practice, AAV are clinically classified according to the severity (nonsevere or severe) and the extent (limited or systemic) of the disease [9]. The definition of disease severity varies slightly according to the studies or guidelines; the latter usually define severe AAV as requiring CYC or rituximab (RTX) for the induction of remission. Organ-threatening manifestations usually include severe alveolar hemorrhage, 
rapidly progressive glomerulonephritis (GN), and severe gastrointestinal, cardiac, central nervous system, or ocular involvement. In clinical trials, the Birmingham Vasculitis Activity score (BVAS) [10] is often used to determine disease activity for GPA and MPA and identify patient with "major" items, corresponding to a severe disease. Furthermore, stratification of the risk of relapse is important in individualizing therapy. Patients with GPA, with a previous history of relapsing disease, and PR3-ANCA are more likely to relapse than patients with MPA or with MPO-ANCA. Other factors may possibly be linked with relapses, such as ANCA status during follow-up, genetic background, levels of T cell activation, and other possible exogenous factors [7].

\section{Treatment Principles}

Treatment of severe GPA and MPA includes induction of remission, followed by maintenance of remission to prevent disease relapse. The cornerstone induction and maintenance trials presented in this review are summarized in Tables 1 and 2, respectively. These studies are also shown on a timeline according to their publication year (Figure 1) $[3,4,11-$ 13]. Knowing the older age of the population affected (peak incidence between 50 and 74 years) and the potential drug toxicity, the past years have been marked with multiple clinical trials aimed at finding the most efficient yet safest regimen for GPA and MPA $[3,4]$.

\section{Induction of Remission}

The remission induction therapy is initiated upon initial diagnosis or relapse of GPA and MPA $[4,11]$. The duration of induction of remission is usually between 3 and 6 months, with the objective of preventing mortality, achieving clinical remission, and limiting permanent organ damage [4]. In addition to age and comorbidities, therapeutic regimen choice is guided by disease severity [11].

4.1. Induction Therapy of Severe GPA and MPA. The current induction therapy of severe GPA and MPA (Figure 2) consists of GC combined with either RTX or CYC $[5,14-16]$.

4.1.1. Glucocorticoids. GC are administered in the induction of remission of severe GPA and MPA [12, 14-16]. Intravenous (IV) methylprednisolone pulses (500-1000 mg per day for 1 to 3 consecutive days) are often used for organ- or life-threatening GPA and MPA, followed by oral prednisone at a dose of $1 \mathrm{mg} / \mathrm{kg}$ daily [12]. The widely accepted use of IV GC pulses has been questioned. In a retrospective multicenter cohort study [17], patients receiving IV methylprednisolone had a significantly higher rate of infection with no benefit in survival, renal recovery, or relapses. Hence, pulses of IV methylprednisolone may be considered in severe, organ or life-threatening GPA or MPA. However, "evidence is lacking to prove its efficacy and shows potential risk of adverse effects, mostly related to increased incidence of infections and diabetes," as emphasized in the recently published CanVasc recommendations [5].

The numerous adverse effects of GC have led to many attempts to reduce their doses and accelerate tapering in clin- ical trials [18]. The Plasma Exchange and Glucocorticoids in Severe ANCA-Associated Vasculitis (PEXIVAS) trial showed that a rapid taper of GC was noninferior to the standard, slower tapering regimen in terms of death or end-stage renal disease (ESRD). At 6 months, the cumulative dose of oral GC in the reduced-dose group was less than $60 \%$ of that in the standard group and was associated with less severe infections during the first year of treatment [19]. The combination of CYC and RTX has also been attempted to accelerate GC tapering [20-22], with some studies limiting the duration of GC treatment to 2 weeks, although strong evidence with randomized controlled trials (RCTs) is lacking.

GC tapering may begin 2 to 4 weeks after initiation of immunosuppression for the induction of remission (with CYC or RTX). It is reasonable to aim for a daily oral dose of prednisone (or equivalent) of 7.5 to $12.5 \mathrm{mg}$ at 3 months of remission induction therapy [19].

4.1.2. Cyclophosphamide. CYC has been widely used in combination with GC to induce remission of GPA and MPA; its efficacy has been proven for over 30 years [23, 24]. In combination with high-dose GC, CYC induces remission in up to $75 \%$ and $90 \%$ of patients, at 3 and 6 months, respectively [7].

CYC can be administered orally or intravenously. The CYCLOPS trial compared daily oral (DO) versus IV pulse CYC in patients with newly diagnosed severe renal GPA or MPA (Table 1). Renal involvement was defined as serum creatinine levels between 150 and $500 \mu \mathrm{mol} / \mathrm{L}$, proteinuria (over $1 \mathrm{~g}$ daily), hematuria, or proven necrotic pauci-immune GN on kidney biopsy. At 9-month follow-up, no significant difference was seen in the time to remission between groups $(p=0.59)$, with a lower cumulative dose of CYC in the IV pulse group (8.2 $\mathrm{g}$ versus $15.9 \mathrm{~g}$ with the DO CYC; $p<0.001$ ) and a lower rate of leukopenia (hazard ratio (HR) 0.41, (CI 0.23 to 0.71$)$ ) [25]. However, long-term follow-up of these patients at a median of 4.3 years showed that relapses were significantly lower in DO CYC than IV pulse CYC (20.8\% versus $39.5 \%$, respectively; HR $0.50,95 \%$ CI 0.26 to $0.93 ; p=0.029$ ), but without any difference in mortality $(p=0.92)$ or renal function $(p=0.82)$ [26].

Therefore, CYC may be given intravenously at a dose of $15 \mathrm{mg} / \mathrm{kg}$ for each infusion (maximum $1200 \mathrm{mg}$ per pulse) at weeks 0,2 , and 4 and then every 3 weeks for a total of 3 to 6 months. If given orally, the daily target dose is $2 \mathrm{mg} / \mathrm{kg}$ (maximum of $200 \mathrm{mg} /$ day) [7, 12]. CYC dosing must be adjusted according to age and glomerular filtration rate (GFR) and subsequently corrected according to the presence and severity of cytopenia.

4.1.3. Rituximab. RTX is a chimeric anti-CD20 monoclonal antibody that depletes B cells. Because of the potential toxicity associated with CYC (cytopenias, infertility, and risk of hemorrhagic cystitis and bladder cancer), RTX has gained popularity for the induction of remission in AAV. Nevertheless, the long-term toxicity of CYC can be minimized by limiting its total lifetime cumulative dose to less $25 \mathrm{~g}[5,27]$.

RTX may be used as a first-line therapy for induction of remission with GC in severe GPA and MPA, especially in 
TABLE 1: Induction therapy studies of ANCA-associated vasculitis discussed in this article.

\begin{tabular}{|c|c|c|c|c|c|c|}
\hline & Trial & Treatment & Study type & Population & Treatment & Outcomes \\
\hline \multirow[t]{2}{*}{ CYC } & $\begin{array}{l}\text { CYCLOPS trial } \\
\text { (2009) }[25]\end{array}$ & \multirow{2}{*}{$\begin{array}{l}\text { CYC daily } \\
\text { oral vs. } \\
\text { CYC IV }\end{array}$} & \multirow[t]{2}{*}{ RCT } & \multirow{2}{*}{$\begin{array}{l}\text { Newly diagnosed severe } \\
\text { GPA or MPA with renal } \\
\text { involvement }\end{array}$} & $\begin{array}{l}\text { IV CYC: } 15 \mathrm{mg} / \mathrm{kg} \text { weeks } 0,2 \text {, } \\
\text { and } 4 \text { then q3 weeks } \\
\text { continued for } 3 \text { months after } \\
\text { remission (maximum } \\
1200 \mathrm{mg} \text { IV/dose) }\end{array}$ & $\begin{array}{l}\text { At } 9 \text { months: no } \\
\text { difference in time to } \\
\text { remission with a lower } \\
\text { rate of leukopenia and } \\
\text { reduced cumulative } \\
\text { dose with IV CYC } \\
\quad(n=149)\end{array}$ \\
\hline & $\begin{array}{c}\text { CYCLOPS } \\
\text { trial-long } \\
\text { term }(2012) \\
{[26]}\end{array}$ & & & & $\begin{array}{c}\text { Oral CYC: } 2 \mathrm{mg} / \mathrm{kg} / \mathrm{day} \text { until } \\
\text { remission then } 1.5 \mathrm{mg} / \mathrm{kg} / \mathrm{day} \\
\text { x } 3 \text { months (maximum oral } \\
\text { dose of } 200 \mathrm{mg} \text { ) }\end{array}$ & $\begin{array}{l}\text { At } 4.3 \text { years of median } \\
\text { follow-up: significantly } \\
\text { lower relapses with oral } \\
\text { CYC; no difference in } \\
\text { mortality or renal } \\
\text { survival }(n=134)\end{array}$ \\
\hline MTX & $\begin{array}{l}\text { NORAM study } \\
\quad(2005)[40]\end{array}$ & $\begin{array}{l}\text { MTX vs. } \\
\text { CYC }\end{array}$ & RCT & $\begin{array}{l}\text { Newly diagnosed GPA or } \\
\text { MPA without critical } \\
\text { organ manifestations } \\
(n=100)\end{array}$ & $\begin{array}{l}\text { Oral CYC: } 2 \mathrm{mg} / \mathrm{kg} / \mathrm{day} \text { until } \\
\text { remission }(3-6 \mathrm{months}) \text { and } \\
\text { then } 1.5 \mathrm{mg} / \mathrm{kg} / \mathrm{day} \text { until } \\
\text { month } 10 \text { and discontinued } \\
\text { by month } 12 \\
\text { Oral MTX: } 20-25 \mathrm{mg} / \text { week } \\
\text { for } 12 \text { months and then } \\
\text { discontinued }\end{array}$ & $\begin{array}{c}\text { At } 6 \text { months: MTX } \\
\text { noninferior for } \\
\text { remission rate; delayed } \\
\text { remission in patients } \\
\text { with more extensive } \\
\text { disease } \\
\text { At } 18 \text { months: } \\
\text { increased relapses with } \\
\text { MTX }\end{array}$ \\
\hline MMF & $\begin{array}{c}\text { MYCYC } \\
(2019)[42]\end{array}$ & $\begin{array}{l}\text { CYC vs. } \\
\text { MMF }\end{array}$ & RCT & $\begin{array}{l}\text { Newly diagnosed GPA or } \\
\text { MPA excluding severe } \\
\text { disease }(n=140)\end{array}$ & $\begin{array}{c}\text { CYC: IV pulse CYC } 15 \mathrm{mg} / \mathrm{kg} \\
\text { q2-3 weeks for } 6 \text { months } \\
\text { MMF: } 2 \text { g/day increased to } \\
3 \text { g/day (if required) for } 3-6 \\
\text { months } \\
\text { Both groups received AZA } \\
2 \text { mg/kg daily as maintenance } \\
\text { therapy }\end{array}$ & $\begin{array}{l}\text { At } 6 \text { months: MMF } \\
\text { noninferior for } \\
\text { remission } \\
\text { At } 18 \text { months: more } \\
\text { disease relapses with } \\
\text { MMF compared to } \\
\text { CYC, especially in PR3- } \\
\text { ANCA patients }\end{array}$ \\
\hline \multirow{3}{*}{ Rituximab } & $\begin{array}{l}\text { RITUXVAS } \\
\text { trial }(2010) \\
{[28]}\end{array}$ & $\begin{array}{l}\text { RTX vs. } \\
\text { CYC }\end{array}$ & RCT & $\begin{array}{l}\text { Newly diagnosed } \\
\text { generalized GPA or MPA } \\
\text { with renal involvement } \\
(n=44)\end{array}$ & $\begin{array}{c}\text { RTX: } 375 \mathrm{mg} / \mathrm{m}^{2} \text { IV weekly x } \\
4 \text { (patients received IV CYC } \\
15 \mathrm{mg} / \mathrm{kg} \text { x } 2 \text { doses at weeks } 0 \\
\text { and } 3 \text { ) } \\
\text { CYC: } 15 \mathrm{mg} / \mathrm{kg} \mathrm{IV} \times 3 \text { to } 6 \\
\text { months and then AZA }\end{array}$ & $\begin{array}{l}\text { At } 12 \text { months: no } \\
\text { significant difference in } \\
\text { sustained remissions, } \\
\text { SAE, and deaths }\end{array}$ \\
\hline & $\begin{array}{l}\text { RAVE trial } \\
(2010) \text { [29] }\end{array}$ & $\begin{array}{l}\text { RTX vs. } \\
\text { CYC }\end{array}$ & RCT & $\begin{array}{l}\text { Newly diagnosed or } \\
\text { severe relapse of GPA or } \\
\text { MPA with positive } \\
\text { ANCA }(n=197)\end{array}$ & $\begin{array}{c}\text { RTX: } 375 \mathrm{mg} / \mathrm{m}^{2} \text { IV q week } \\
\text { x } 4 \\
\text { Oral CYC: } 2 \mathrm{mg} / \mathrm{kg} / \text { day x } 3-6 \\
\text { months until remission and } \\
\text { then AZA ( } 2 \mathrm{mg} / \mathrm{kg} / \text { day })\end{array}$ & $\begin{array}{l}\text { At } 6 \text { months: RTX } \\
\text { noninferior for } \\
\text { remission (BVAS }=0 \\
\text { and successful } \\
\text { completion of } \\
\text { prednisone tapering) } \\
\text { At } 6 \text { months: RTX } \\
\text { superior for relapsing } \\
\text { vasculitis or PR3- } \\
\text { positive patients }\end{array}$ \\
\hline & $\begin{array}{c}\text { RAVE } \\
\text { trial-long } \\
\text { term }(2013) \\
{[30]}\end{array}$ & & & & & $\begin{array}{l}\text { At } 18 \text { months: RTX } \\
\text { noninferior for } \\
\text { remission }(\mathrm{BVAS}=0)\end{array}$ \\
\hline $\begin{array}{l}\text { Reduced } \\
\text { GC }\end{array}$ & $\begin{array}{l}\text { Glucocorticoid } \\
\text { (Pepper et al.) } \\
\text { (2018) [22] }\end{array}$ & $\begin{array}{l}\text { Standard } \\
\text { vs. reduced } \\
\text { GC }\end{array}$ & $\begin{array}{l}\text { Multicenter } \\
\text { cohort } \\
\text { study }\end{array}$ & $\begin{array}{l}\text { Active MPO- or PR3- } \\
\text { ANCA vasculitis or } \\
\text { ANCA-negative pauci- } \\
\text { immune GN }(n=49)\end{array}$ & $\begin{array}{l}\text { Induction therapy with two } \\
\text { doses of RTX and three } \\
\text { months of low-dose pulse IV } \\
\text { CYC followed by short course } \\
\text { (1 to } 2 \text { weeks) of GC }\end{array}$ & $\begin{array}{l}\text { Similar outcomes to a } \\
\text { matched population } \\
\text { from the EUVAS trials, } \\
\text { with lower exposure to } \\
\text { CYC and GC }\end{array}$ \\
\hline
\end{tabular}


TABLE 1: Continued.

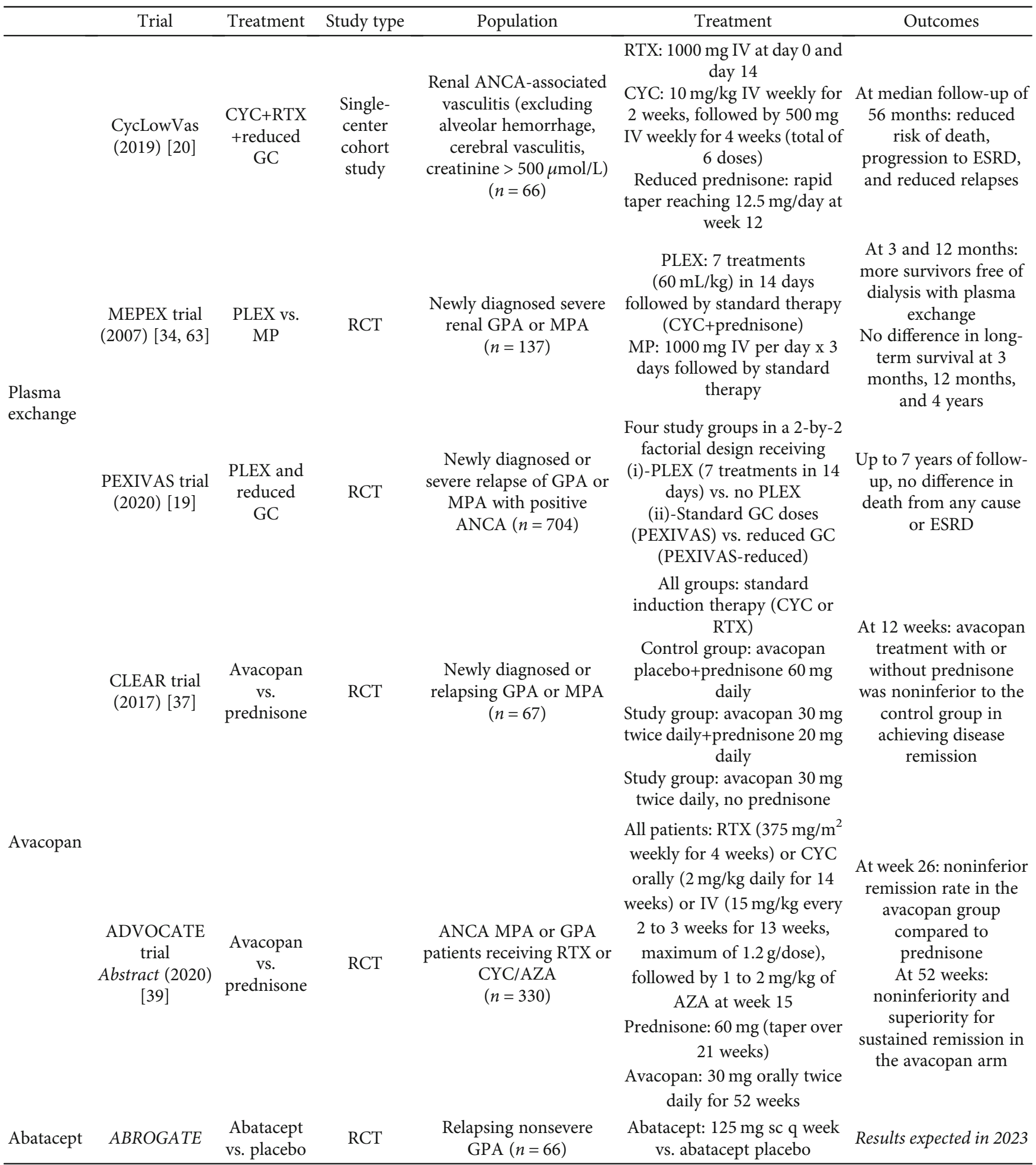

Abbreviations: ad = until; $\mathrm{ANCA}=$ antineutrophil cytoplasmic antibody; $\mathrm{AZA}=$ azathioprine; $\mathrm{CYC}=$ cyclophosphamide; $\mathrm{ESRD}=$ end-stage renal disease; $\mathrm{GC}$ = glucocorticoid; GFR = glomerular filtration rate; GN = glomerulonephritis; GPA = granulomatosis with polyangiitis; IV = intravenous; MMF = mycophenolate mofetil; $\mathrm{MP}=$ methylprednisolone; $\mathrm{MPA}=$ microscopic polyangiitis; $\mathrm{MTX}=$ methotrexate; $\mathrm{q}=$ every; PLEX = plasma exchange; RCT = randomized controlled trial; $\mathrm{RTX}=$ rituximab; $\mathrm{SAE}=$ severe adverse events; $\mathrm{sc}=$ subcutaneous; $\mathrm{vs.}=$ versus; $\mathrm{x}=$ times. 
TABLE 2: Maintenance therapy trials of ANCA-associated vasculitis discussed in this article.

\begin{tabular}{|c|c|c|c|c|c|c|}
\hline & Trial & Therapy & $\begin{array}{c}\text { Study } \\
\text { type }\end{array}$ & Population & Doses & Outcomes \\
\hline CYC & $\begin{array}{l}\text { CYCAZAREM } \\
\text { trial (2003) [45] }\end{array}$ & CYC vs. AZA & RCT & $\begin{array}{l}\text { Newly diagnosed } \\
\text { generalized ANCA- } \\
\text { associated vasculitis after } \\
\text { induction with GC and } \\
\text { oral CYC. }(n=144)\end{array}$ & $\begin{array}{l}\text { CYC: } 1.5 \mathrm{mg} / \mathrm{kg} / \text { day for } \\
12 \mathrm{months} \\
\text { AZA: } 2 \mathrm{mg} / \mathrm{kg} / \text { day for } 12 \\
\text { months } \\
\text { Both arms received after } \\
\text { AZA until month } 12\end{array}$ & $\begin{array}{l}\text { No difference in relapse } \\
\text { and adverse events at } 18 \\
\text { months of follow-up }\end{array}$ \\
\hline MMF & $\begin{array}{l}\text { IMPROVE trial } \\
\quad(2010)[47]\end{array}$ & $\begin{array}{l}\text { AZA vs. } \\
\text { MMF }\end{array}$ & RCT & $\begin{array}{l}\text { Newly diagnosed GPA or } \\
\text { MPA after induction with } \\
\text { GC and CYC. }(n=156)\end{array}$ & $\begin{array}{c}\text { AZA: } 2 \mathrm{mg} / \mathrm{kg} / \text { day for } 12 \\
\text { months, then } \\
1.5 \mathrm{mg} / \mathrm{kg} / \text { day for } 6 \\
\text { months, and } 1 \mathrm{mg} / \mathrm{kg} / \text { day } \\
\text { until month } 42 \\
\text { MMF: } 2000 \mathrm{mg} / \text { day for } 12 \\
\text { months, then } 1500 \mathrm{mg} \text { for } \\
6 \text { months, and } 1000 \mathrm{mg} \\
\text { until month } 42\end{array}$ & $\begin{array}{l}\text { At median follow-up of } 39 \\
\text { months: increased } \\
\text { incidence of first relapse in } \\
\text { the MMF group compared } \\
\text { to AZA; increased } \\
\text { incidence of first major } \\
\text { relapse in the MMF group } \\
\text { compared to AZA }\end{array}$ \\
\hline MTX & $\begin{array}{l}\text { WEGENT trial } \\
(2008)[43]\end{array}$ & MTX vs. AZA & RCT & $\begin{array}{l}\text { Newly diagnosed GPA or } \\
\text { MPA with positive } \\
\text { serologic or histological }\end{array}$ & $\begin{array}{c}\text { AZA: } 2 \mathrm{mg} / \mathrm{kg} / \mathrm{day} \text { for } 12 \\
\text { months } \\
\text { MTX: } 0.3 \mathrm{mg} / \mathrm{kg} / \text { week } \\
\text { (oral or subcutaneous), }\end{array}$ & $\begin{array}{l}\text { At median follow-up of } 29 \\
\text { months: No difference in } \\
\text { adverse reactions and } \\
\text { relapses }(n=126)\end{array}$ \\
\hline & $\begin{array}{l}\text { WEGENT } \\
\text { trial-long term } \\
(2016)[44]\end{array}$ & & & $\begin{array}{l}\text { ANCA, after induction } \\
\text { with GC and CYC }\end{array}$ & $\begin{array}{l}\text { progressively increasing } \\
\text { to } 25 \mathrm{mg} / \text { week for } 12 \\
\text { months }\end{array}$ & $\begin{array}{l}\text { At } 10 \text { years: no significant } \\
\text { difference in relapse-free } \\
\text { survival }(n=112)\end{array}$ \\
\hline AZA & $\begin{array}{l}\text { REMAIN trial } \\
(2017)[46]\end{array}$ & $\begin{array}{l}\text { Prolonged } \\
\text { AZA } \\
\text { treatment for } \\
\text { maintenance }\end{array}$ & RCT & $\begin{array}{l}\text { Newly diagnosed GPA or } \\
\text { MPA or renal-limited } \\
\text { vasculitis after induction } \\
\text { with GC and CYC }(n=117 \\
\text { ) }\end{array}$ & $\begin{array}{l}\text { Maintenance with AZA } \\
\text { and prednisone low dose } \\
\text { for } 24 \text { vs. } 48 \text { months }\end{array}$ & $\begin{array}{l}\text { Significant reduction of } \\
\text { relapse with } 48 \text { months of } \\
\text { treatment compared to } 24 \\
\text { months; ANCA positivity } \\
\text { at randomization } \\
\text { associated with relapse risk }\end{array}$ \\
\hline \multirow{3}{*}{ Rituximab } & $\begin{array}{l}\text { MAINRITSAN- } \\
\text { 1-60 months } \\
(2018)[53]\end{array}$ & RTX vs. AZA & RCT & $\begin{array}{l}\text { Newly diagnosed or relapse } \\
\text { of severe GPA or MPA or } \\
\text { renal-limited vasculitis in } \\
\text { complete remission after } \\
\text { induction therapy with GC } \\
\text { and CYC }(n=115)\end{array}$ & $\begin{array}{l}\text { RTX: } 500 \mathrm{mg} \text { IV at days } 0 \\
\text { and } 14 \text { and then at } \\
\text { months } 6,12 \text {, and } 18 \\
\text { (total } 18 \mathrm{months}) \\
\text { AZA: } 2 \mathrm{mg} / \mathrm{kg} / \text { day for } 12 \\
\text { months, } 1.5 \mathrm{mg} / \mathrm{kg} / \text { day } \\
\text { for } 6 \text { months, and then } \\
1 \mathrm{mg} / \mathrm{kg} / \text { day for } 4 \text { months } \\
\text { (total: } 22 \text { months) }\end{array}$ & $\begin{array}{l}\text { At } 60 \text { months: improved } \\
\text { survival and increased } \\
\text { major relapse-free survival } \\
\text { with RTX }\end{array}$ \\
\hline & $\begin{array}{l}\text { MAINRITSAN- } \\
2 \text { (2018) [54] }\end{array}$ & $\begin{array}{l}\text { Fixed RTX vs. } \\
\text { individualized }\end{array}$ & RCT & $\begin{array}{l}\text { Newly diagnosed or } \\
\text { relapsing severe GPA or } \\
\text { MPA in complete } \\
\text { remission after induction } \\
\text { therapy with GC and CYC } \\
\text { or RTX }(n=162)\end{array}$ & $\begin{array}{l}\text { Fixed: } 500 \mathrm{mg} \text { IV at days } 0 \\
\text { and } 14 \text { and then at } 6,12 \text {, } \\
\text { and } 18 \text { months } \\
\text { Individualized: } 500 \mathrm{mg} \text { IV } \\
\text { at randomization and } \\
\text { then reinfusion only if } \\
\text { reappearance of CD } 19 \text { or } \\
\text { ANCA or increased titer } \\
\text { of ANCA; measured every } \\
3 \text { months, until month } 18\end{array}$ & $\begin{array}{l}\text { Median of } 5 \text { vs. } 3 \text { infusions } \\
\text { in } 2 \text { years, respectively } \\
\text { At } 28 \text { months of follow-up: } \\
\text { no significant difference in } \\
\text { relapse rate; ANCA and } \\
\text { CD19 measured every } 3 \\
\text { months do not predict } \\
\text { relapse }\end{array}$ \\
\hline & $\begin{array}{l}\text { MAINRITSAN- } \\
3(2020)[55]\end{array}$ & $\begin{array}{l}\text { RTX } 2 \text { vs. } 4 \\
\text { years }\end{array}$ & RCT & $\begin{array}{l}\text { Newly diagnosed or } \\
\text { relapsing severe GPA or } \\
\text { MPA in complete } \\
\text { remission following the } \\
\text { completion of } \\
\text { MAINRITSAN-2 trial } \\
(n=97)\end{array}$ & $\begin{array}{c}\text { Four additional } 500 \mathrm{mg} \text { IV } \\
\text { doses of RTX: at } \\
\text { inclusion, months } 34,40 \text {, } \\
\text { and } 46 \text { vs. placebo }\end{array}$ & $\begin{array}{l}\text { At } 56 \text { months: relapse-free } \\
\text { survival rates superior with } \\
\text { RTX with no difference in } \\
\text { severe adverse events }\end{array}$ \\
\hline
\end{tabular}


TABLE 2: Continued.

\begin{tabular}{|c|c|c|c|c|c|c|}
\hline & Trial & Therapy & $\begin{array}{c}\text { Study } \\
\text { type }\end{array}$ & Population & Doses & Outcomes \\
\hline & $\begin{array}{c}\text { RITAZAREM } \\
\text { Abstract (2019) } \\
{[56]}\end{array}$ & RTX vs. AZA & RCT & $\begin{array}{l}\text { Maintenance therapy after } \\
\text { a major relapse of GPA or } \\
\text { MPA after induction with } \\
\text { GC+RTX }(n=170)\end{array}$ & $\begin{array}{l}\text { RTX: } 1000 \mathrm{mg} \text { IV every } 4 \\
\text { months x } 5 \text { doses } \\
\text { AZA: } 2 \mathrm{mg} / \mathrm{kg} / \text { day }\end{array}$ & $\begin{array}{c}\text { At } 24 \text { months of follow-up: } \\
\text { RTX superior to AZA to } \\
\text { prevent relapses }\end{array}$ \\
\hline \multirow[t]{2}{*}{ Belimumab } & $\begin{array}{l}\text { BREVAS trial } \\
(2019)[58]\end{array}$ & $\begin{array}{l}\text { Belimumab } \\
\text { vs. placebo }\end{array}$ & RCT & $\begin{array}{l}\text { Newly diagnosed or } \\
\text { relapsing severe GPA or } \\
\text { MPA after induction with } \\
\text { GC and either CYC or } \\
\text { RTX }(n=105)\end{array}$ & $\begin{array}{c}\text { All patients: AZA } \\
\text { (2 mg/kg/day) and low- } \\
\text { dose GC } \\
\text { Belimumab: } 10 \mathrm{mg} / \mathrm{kg} \mathrm{IV} \\
\text { on days } 0,14 \text {, and } 28 \text { and } \\
\text { then every } 28 \text { days vs. } \\
\text { placebo of belimumab }\end{array}$ & $\begin{array}{l}\text { At } 12 \text { months: no } \\
\text { difference in vasculitis } \\
\text { relapse } \\
\text { No relapsing disease in } \\
\text { patients receiving RTX } \\
\text { followed by belimumab }\end{array}$ \\
\hline & COMBIVAS & $\begin{array}{l}\text { Belimumab } \\
+ \text { RTX vs. } \\
\text { RTX alone }\end{array}$ & RCT & $\begin{array}{l}\text { Patients with PR3-positive } \\
\text { AAV }(n=30)\end{array}$ & $\begin{array}{l}\text { Rituximab: } 1 \text { g IV x } 2 \\
\text { doses (all patients) } \\
\text { Belimumab group: } \\
200 \text { mg sc q week }\end{array}$ & Results expected in 2023 \\
\hline \multirow[t]{2}{*}{ Prednisone } & TAPIR trial & $\begin{array}{l}\text { Low-dose } \\
\text { prednisone }\end{array}$ & $\begin{array}{l}\text { Open } \\
\text { label }\end{array}$ & GPA in remission $(n=60)$ & $\begin{array}{l}\text { All patients tapered to } \\
5 \mathrm{mg} \text { of daily prednisone } \\
\text { and then randomized } \\
\text { Prednisone: } 5 \mathrm{mg} \text { daily } \\
\text { No prednisone: taper to } \\
0 \mathrm{mg}\end{array}$ & $\begin{array}{l}\text { Results pending } \\
\text { Endpoint: rate of relapse } \\
\text { being the endpoint at } 6 \\
\text { months after } \\
\text { randomization }\end{array}$ \\
\hline & $\begin{array}{l}\text { MAINEPSAN } \\
\text { trial }\end{array}$ & $\begin{array}{l}\text { Low-dose } \\
\text { prednisone }\end{array}$ & $\mathrm{RCT}$ & $\begin{array}{l}\text { Patients with GPA or MPA } \\
\text { in remission, } 12 \text { months } \\
\text { following induction } \\
\text { therapy }\end{array}$ & $\begin{array}{c}\text { Prednisone: continue } \\
5 \mathrm{mg} \text { daily for } 12 \text { months } \\
\text { No prednisone: taper to } \\
0 \text { mg in } 1 \text { month }\end{array}$ & Recruiting in France \\
\hline
\end{tabular}

Abbreviations: $\mathrm{ANCA}=$ antineutrophil cytoplasmic antibody; $\mathrm{AZA}=$ azathioprine; $\mathrm{CYC}=$ cyclophosphamide; $\mathrm{GC}=$ glucocorticoids; $\mathrm{GPA}=$ granulomatosis with polyangiitis; GFR = glomerular filtration rate; $\mathrm{GN}=$ glomerulonephritis; IV = intravenous; $\mathrm{MMF}=$ mycophenolate mofetil; $\mathrm{MPA}=$ microscopic polyangiitis; $\mathrm{q}=$ every; $\mathrm{RCT}$ = randomized controlled trial; RTX = rituximab; sc = subcutaneous.

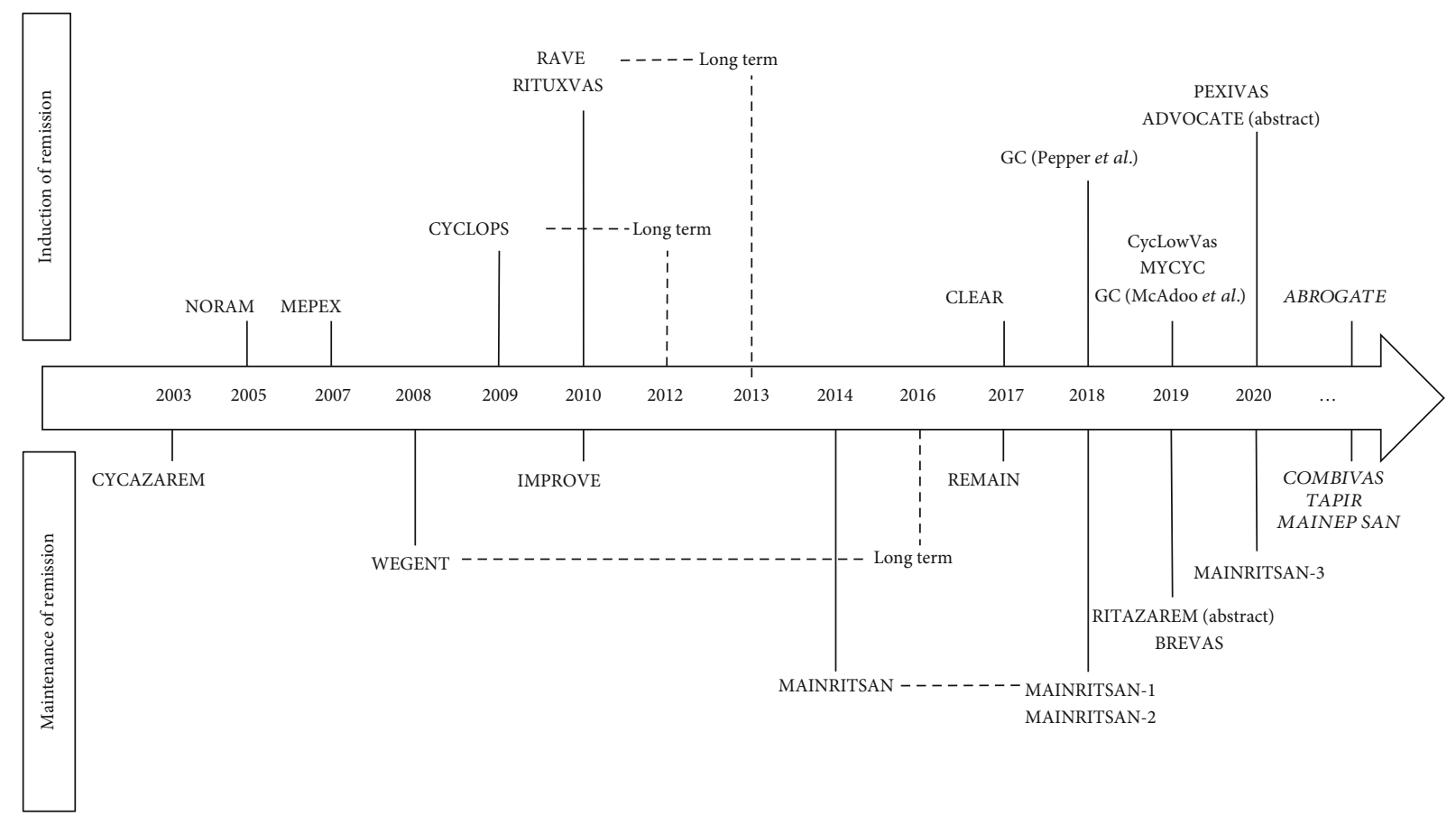

FIGURE 1: Timeline of hallmark trials of ANCA-associated vasculitis. 


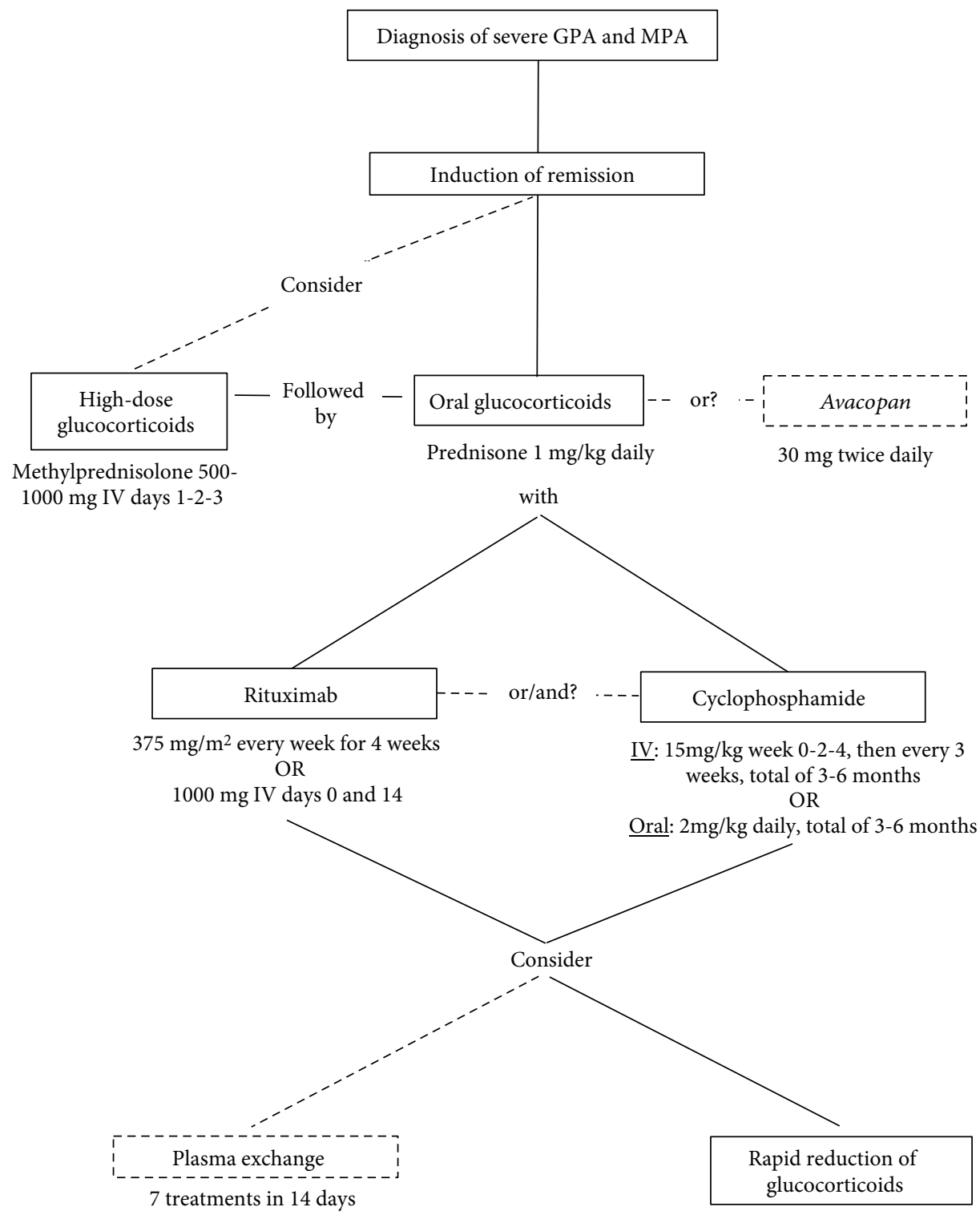

FIGURE 2: Suggested algorithm of induction therapy in severe GPA or MPA.

patients with contraindications to CYC [5]. Two main RCTs compared CYC and RTX head to head.

The RITUXVAS trial was conducted as an open-label randomized study and included patients with newly diagnosed generalized GPA or MPA with renal involvement (median GFR below $18 \mathrm{~mL} / \mathrm{min} / 1.73 \mathrm{~m}^{2}$ ). Participants in the CYC group received the drug intravenously for 3 to 6 months, followed by azathioprine (AZA). Patients in the RTX group received $375 \mathrm{mg} / \mathrm{m}^{2}$ every week for 4 weeks, with 2 pulses of IV CYC $(15 \mathrm{mg} / \mathrm{kg})$ with the first and the third RTX infusion. Comparing CYC to RTX (Table 1), there was no significant difference in sustained remissions $(p=0.68)$, severe adverse reactions $(p=0.77)$, or deaths $(p=1.00)$ at 12 months of follow-up. In RITUXVAS, RTX was equivalent to CYC, but not superior for induction of remission [28].

The Rituximab in ANCA-Associated Vasculitis (RAVE) trial, a noninferiority double-blinded RCT, studied patients with severe newly diagnosed or relapsing GPA or MPA, with positive ANCA and a BVAS/WG > 3. At 6-month follow-up, remission, defined as a BVAS $=0$ and a successful complete tapering of prednisone, was noninferior with RTX compared to CYC, respectively, $64 \%$ versus $53 \%$ ( $p<0.001$ for noninferiority). In patients with relapsing GPA or MPA, RTX was shown superior to CYC $(67 \%$ versus $42 \% ; p=0.01)$ for remission induction at 6 months [29]. A longer follow-up of the relapsing patients confirmed that RTX was superior to CYC at 12 months' follow-up (48\% versus 39\%, $p=0.009)$, but no longer at 18 months $(p=0.06)$. For newly diagnosed and relapsing patients combined, remission at 18 months with RTX was noninferior to CYC (39\% and 33\%, respectively, $p<0.001)$. However, it is important to note that patients in the CYC received AZA after 3 to 6 months of treatment with CYC, whereas the RTX group received no further treatment [30]. Interestingly, patients with PR3-ANCApositive antibodies doubled their chances of remission at 6 
months with RTX when compared to a matched population receiving CYC [31].

Although the 4-dose RTX regimen $\left(375 \mathrm{mg} / \mathrm{m}^{2}\right.$ weekly for 4 weeks) has been most extensively studied for induction therapy in AAV, many clinicians choose to use the 2-dose regimen ( $1000 \mathrm{mg}$ IV on days 0 and 14 , as used for rheumatoid arthritis) to reduce infusion frequency, total dose, and cost. A recent meta-analysis compared the efficacy and safety of these two RTX regimens for the induction of remission in severe AAV [32]. No difference was found in terms of efficacy and safety between the 4-dose and 2-dose RTX regimens. However, head-to-head clinical trials comparing these two regimens have not yet been conducted.

4.1.4. Combination Rituximab and Cyclophosphamide. The CycLowVas induction of remission cohort study showed a reduction in risk of death (HR $0.29 ; p=0.004)$, progression to ESRD (HR 0.20; $p=0.007$ ), and relapses (HR 0.49; $p=0.04)$ in the CYC and RTX combination group, with rapid GC tapering [20] (doses in Table 1). Similar regimens prospectively studied were shown to be effective and safe [21]. However, as previously mentioned, further trials are needed to confirm the safety and superiority of the combination regimen. Moreover, promising results emerge from studies using low-dose GC. Nevertheless, trials with more statistical power are needed to safely recommend lower dose and shorter GC and CYC regimens [22].

4.1.5. Plasma Exchange. The rationale behind plasma exchange (PLEX) is to reduce circulating serum ANCA levels, as the pathogenic role of ANCA, especially MPOANCA, is well supported by animal models [33]. Two major trials studied the use of PLEX in GPA and MPA.

The MEPEX trial compared PLEX to IV pulse methylprednisolone and included patients with GPA or MPA and pauci-immune GN confirmed on renal biopsy with a serum creatinine above $500 \mu \mathrm{mol} / \mathrm{L}$. At 3 months of follow-up, $69 \%$ of participants survived free of dialysis in the PLEX group compared to $49 \%$ in the standard pulse therapy $(p=0.02)$. At 12 months, $59 \%$ of patients in the plasma exchange group survived free of dialysis versus $43 \%$ with pulse therapy $(p=0.008)$, yet no difference was shown in long-term survival at 3 months, 12 months, and 4 years. However, long-term analyses were limited by the low statistical power related to an uneven loss of patients in the study groups [34].

Thirteen years later, the PEXIVAS trial studied four groups of patients in a 2-by-2 factorial design, to assess the efficacy of a reduced-dose GC regimen and PLEX for induction of remission in GPA and MPA. A total of 704 participants with newly diagnosed or severe relapsing GPA or MPA with positive ANCA were included. Severe disease was defined as active GN on biopsy or on urine sediment, with a GFR below $50 \mathrm{~mL} / \mathrm{min} / 1.73 \mathrm{~m}^{2}$, or pulmonary hemorrhage (with compatible pulmonary imaging and either hemoptysis, positive bronchoalveolar lavage, unexplained anemia, or increased diffusing capacity of carbon dioxide). Initial randomization assigned patients to undergo PLEX or not and to receive standard or reduced GC regimen. No sur- vival difference was shown with PLEX; death or ESRD was observed in $28.4 \%$ of participants at up to 7 years of followup in the PLEX group compared to $31.0 \%$ in the control group $(p=0.27)$ [19].

Therefore, urgent PLEX does not need to be routinely performed in most cases of severe AAV. However, caution must be exerted as some subsets of patients with very severe AAV were underrepresented in PEXIVAS, notably patients with diffuse crescentic GN, with creatinine levels above $500 \mu \mathrm{mol} / \mathrm{L}$, and those requiring hemodialysis and/or affected with severe diffuse pulmonary hemorrhage (DAH). The potential benefit of PLEX in patients with DAH and requiring mechanical ventilation has previously been suggested [35]. Renal response to PLEX might also be predicted by the renal histopathological classification and not solely by the serum creatinine levels [36].

4.1.6. Avacopan. The central role of neutrophil activation in the pathogenesis of AAV is well described [4]. Avacopan, a selective antagonist of the C5a receptor on neutrophils, has anti-inflammatory properties without causing immunosuppression; it blocks the alternative complement cascade in a way that prevents tissue damage while allowing neutrophils to exert their protective functions. Avacopan was compared to prednisone in three trials, two of which are presented here. The small, open-label, and exploratory CLEAR study, a phase 2 trial, enrolled patients with newly diagnosed or severe relapsing GPA or MPA. Participants were randomized in three groups: oral prednisone plus placebo (control group), oral low-dose prednisone plus avacopan, and avacopan without prednisone (doses in Table 2). At 12 weeks of follow-up, treatment with avacopan alone and combined with prednisone was shown noninferior to the control group in achieving disease response ( $p=0.01$ in the avacopan alone group and $p=0.002$ in the avacopan plus prednisone group) [37].

Prednisone and avacopan were then compared in a randomized, placebo-controlled phase 3 trial, the Avacopan in Antineutrophil Cytoplasmic Antibody- (ANCA-) Associated Vasculitis (ADVOCATE) trial [NCT02994927] [38]. Patients with newly diagnosed or relapsing GPA or MPA were randomized to receive prednisone or the study drug, oral avacopan. Patients from both groups were treated with RTX ( $375 \mathrm{mg} / \mathrm{m}^{2}$ weekly for 4 weeks) or CYC, followed by 1 to $2 \mathrm{mg} / \mathrm{kg}$ of AZA. CYC was given orally $(2 \mathrm{mg} / \mathrm{kg}$ daily for 14 weeks) or IV ( $15 \mathrm{mg} / \mathrm{kg}$ every 2 to 3 weeks for 13 weeks, with a maximum of $1200 \mathrm{mg} / \mathrm{dose}$ ). Participants in the avacopan group received oral avacopan $(30 \mathrm{mg}$ twice daily) for 52 weeks and a placebo prednisone taper. Participants in the prednisone arm received oral doses starting at $60 \mathrm{mg}$ daily, tapered to $0 \mathrm{mg}$ over 20 weeks, and a placebo of avacopan. Remission was defined as BVAS $=0$ and discontinuation of GC within 4 weeks before week 26, sustained until week 52. Avacopan was proven noninferior in inducing remission at 26 weeks of follow-up $(72.3 \%$ in the avacopan group versus $70.1 \%$ in the prednisone group; $p<0.0001$ for noninferiority). Avacopan remained noninferior and even superior to prednisone at 52 weeks for sustained remission (65.7\% in the avacopan arm versus $54.9 \%$ in the prednisone arm; $p=0.0066$ for superiority). The study drug was also able 
to further improve kidney function when compared to prednisone and to reduce cumulative GC toxicity [39].

Considering the importance of GC-induced toxicity in the treatment of AAV, the development of safe reduced GC regimens, as in PEXIVAS, CycLowVas, and ADVOCATE trials, is encouraging and marks the impressive evolution of clinical research in AAV.

4.2. Induction of Remission in Nonsevere GPA and MPA. The induction of remission in nonsevere GPA and MPA (without organ- or life-threatening manifestations) usually involves GC in combination with either methotrexate (MTX) or mycophenolate mofetil (MMF). RTX maybe be used; however, it has not been thoroughly investigated in nonsevere GPA and MPA. A lower dose of oral prednisone, $0.5 \mathrm{mg} / \mathrm{kg}$ daily (or equivalent), can often be used initially and tapered 2 to 4 weeks after initiation of immunosuppressive therapy. Such a reduced-dose tapering schedule is a reasonable approach for patients with nonsevere AAV and may be adjusted according to clinical response and delay of action of the additional immunosuppressant chosen.

4.2.1. Methotrexate. The Nonrenal Wegener's Granulomatosis Treated Alternatively with Methotrexate (NORAM) trial compared CYC to MTX in newly diagnosed early systemic ANCA-associated vasculitis without critical organ manifestations. Both treatments were administered for 12 months. The remission rate at 6 months of this unblinded trial was noninferior with MTX compared to CYC (89.8\% versus 93.5\%, $p=0.041$ ). However, in patients with extensive disease or pulmonary involvement, time to achieve remission was longer with MTX as opposed to CYC. At 18 months, relapses were more common in patients treated with MTX than CYC (69.5\% versus $46.5 \%$; $p=0.023)$, which demonstrated at that time the importance of immunosuppressive therapy beyond 12 months [40]. MTX may therefore be used for induction of remission of nonsevere $\mathrm{AAV}$, at weekly doses of $0.3 \mathrm{mg} / \mathrm{kg}$ orally or subcutaneously, with a maximum dose of $25 \mathrm{mg}$. Maintenance of remission therapy is recommended in most cases once remission is achieved and will be further discussed below [12, 14-16].

4.2.2. Mycophenolate Mofetil. MMF, an immunosuppressant that acts selectively on lymphocytes, is used for various autoimmune diseases and for organ transplantation [41]. In the Mycophenolate Mofetil versus Cyclophosphamide for Remission Induction in AAV (MYCYC) trial, MMF was compared to CYC in newly diagnosed GPA or MPA. Participants with life-threatening vasculitis, rapidly progressive GN, or a GFR below $15 \mathrm{~mL} / \mathrm{min} / \mathrm{m}^{2}$ were excluded. At induction of remission, participants received standard GC therapy and either $2000 \mathrm{mg}$ of MMF daily, which was increased to $3000 \mathrm{mg}$ if remission was not achieved at 4 weeks, or $15 \mathrm{mg} / \mathrm{kg}$ of IV CYC pulse every 2-3 weeks. Once remission was achieved, both groups received AZA $2 \mathrm{mg} / \mathrm{kg}$ daily as maintenance therapy. MMF was noninferior to CYC to induce remission at 6 months ( $67 \%$ vs. $61 \%$, respectively, risk difference of $5.7 \%, 90 \%$ CI $(-7.5-19 \%))$. However, patients receiving $\mathrm{MMF}$ as an induction therapy had a higher relapse rate in the following 6 months after achieving remission ( $p=0.049)$ [42]. Hence, MMF, up to $3000 \mathrm{mg}$ daily, can be considered in induction of remission of patients with nonsevere $\mathrm{AAV}$.

\section{Maintenance of Remission Therapy}

Once remission is achieved, maintenance of remission (Figure 3) is important to prevent disease relapses. Vasculitis disease flares after achieving remission may occur in 5-50\% of patients on maintenance therapy and in up to $80-90 \%$ of patients if no maintenance therapy is initiated [13]. Many factors, several still unknown, influence the risk of disease flare; patients with GPA, previous history of relapse(s), and PR3-ANCA positive are more likely to relapse (again) than patients with MPA [7] or with MPO-ANCA [7]. The most widely used therapies for maintenance of remission include MTX, AZA, and RTX. In certain cases, MMF or leflunomide (LEF) may be used. The role of prednisone in the maintenance of remission will also be discussed.

5.1. Methotrexate, Azathioprine, Mycophenolate Mofetil, and Leflunomide. The safety of MTX in maintenance therapy was evaluated in the Wegener's Granulomatosis-Entretien (WEGENT) trial. Patients with newly diagnosed GPA or MPA and positive serologic testing or biopsy were enrolled in this study that compared MTX to AZA (doses in Table 2) for maintenance of remission. At median followup of 29 months, no difference in adverse reactions or relapses was noted between MTX and AZA, with $33 \%$ and $36 \%$ of participants relapsing, respectively $(p=0.71)$ [43]. Longer follow-up of the same cohort of patients evaluated the rate of relapses or adverse events after discontinuation of the two drugs [44]. No significant difference was proven in relapse-free survival $33.5 \%$ in the MTX group versus $26.3 \%$ in the AZA group; $p=0.29$ ) and in overall survival (79.9\% in the MTX group versus $75.1 \%$ in the AZA group; $p=0.56)$ at 10 years of follow-up after maintenance treatment.

The Cyclophosphamide versus Azathioprine as Remission Maintenance Therapy for ANCA-Associated Vasculitis Study (CYCAZAREM) compared continuous CYC versus a switch to AZA for maintenance of remission (doses in Table 2). Participants with newly diagnosed generalized AAV initially all received prednisone and oral CYC $(2 \mathrm{mg} / \mathrm{kg}$ per day). Once remission was achieved between 3 to 6 months after treatment initiation, patients were randomized to continue oral CYC $(1.5 \mathrm{mg} / \mathrm{kg}$ per day) or replace it with AZA ( $2 \mathrm{mg} / \mathrm{kg}$ daily) for 12 months. All participants were switched to AZA after 12 months. No difference in relapse rate was noted at 18 months' follow-up (15.5\% for AZA and $13.7 \%$ for CYC; $p=0.65$ ) [45]. Because of the potential adverse effects of CYC, switching to AZA for maintenance therapy after induction of remission achieved with CYC was deemed safer and appropriate [12, 14-16].

The duration of maintenance therapy with AZA was studied in the prolonged Remission-Maintenance Therapy in Systemic Vasculitis (REMAIN) trial. A significant reduction of relapse rates was noted with 48 months of treatment 

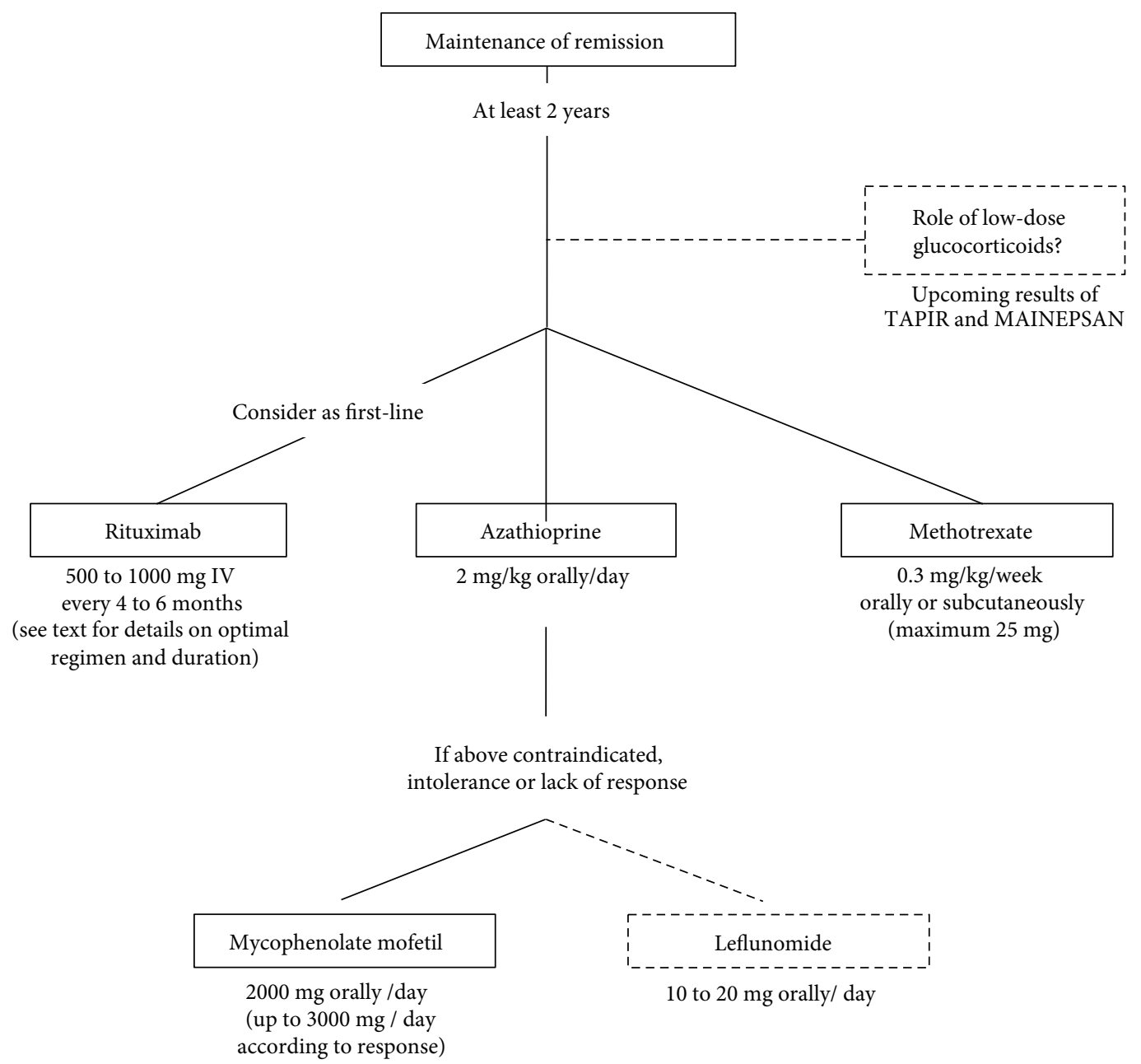

FIgURE 3: Suggested algorithm of maintenance therapy in severe GPA and MPA.

compared to 24 months only, of $22 \%$ and $63 \%$, respectively $(p<0.0001)$. Interestingly, ANCA positivity at randomization was a predictor of relapse [46].

Subsequently, AZA was compared to MMF for maintenance therapy in the International Mycophenolate Mofetil Protocol to Reduce Outbreaks of Vasculitides (IMPROVE) trial. All patients achieved remission with GC and CYC and then were randomized to receive daily AZA $(2 \mathrm{mg} / \mathrm{kg}$ for 12 months, $1.5 \mathrm{mg} / \mathrm{kg}$ for 6 months, and $1 \mathrm{mg} / \mathrm{kg}$ until month 42) or daily MMF (2000 mg for 12 months, $1500 \mathrm{mg}$ for 6 months, and $1000 \mathrm{mg}$ until month 42). At median followup of 39 months, an increased incidence of first relapses occurred in the MMF group compared to AZA (HR 1.69; 95\% CI 1.06-2.07; $p=0.03$ ). Moreover, a higher incidence of first major relapse was shown in the first group compared to the latter (HR 2.14; 95\% CI 0.99-4.64; $p=0.054$ ) [47]. Consequently, AZA is considered a better option than MMF to maintain remission in patients with GPA or MPA.

LEF exerts anti-inflammatory and immunomodulatory effects through activation of p53, resulting in the inhibition of the proliferation of lymphocytes [48]. LEF was compared to MTX for maintenance of remission. Patients with generalized GPA were enrolled in a RCT to receive MTX or LEF after induction therapy with CYC. Participants in the LEF arm had significantly fewer major relapses $(p=0.037)$ in the 2 years following remission [49]. More recently, LEF was described in a retrospective study as an induction and maintenance therapy in 93 participants with different vasculitides, including 45 patients with GPA and 8 patients with MPA. Most patients had low-dose prednisone and $89 \%$ had an active disease at treatment initiation. In patients with GPA, 69\% achieved remission at 6 months [50]. Hence, although evidence is limited, LEF may be considered as an alternative agent for maintenance therapy in AAV [51].

5.2. Rituximab for Maintenance of Remission. Evidence around RTX in maintenance therapy comes mainly from a series of trials called the MAINRITSAN trials (Table 2). The first Maintenance of Remission using Rituximab in Systemic ANCA-Associated Vasculitis (MAINRITSAN) study included newly diagnosed, severe relapsing GPA or MPA, or renal-limited ANCA-associated vasculitis. Patients received the standard induction treatment with prednisone and CYC until remission and then were randomized to receive either RTX for 18 months or AZA for 22 months. RTX dosing was $500 \mathrm{mg}$ IV at days 0 and 14 and then at 
months 6,12 , and 18 . Oral AZA was given at $2 \mathrm{mg} / \mathrm{kg}$ daily for 12 months, $1.5 \mathrm{mg} / \mathrm{kg}$ daily for 6 months, and then $1 \mathrm{mg} / \mathrm{kg}$ daily for 4 months, for a total of 22 months. At 28 months of follow-up, major relapses occurred less frequently in the RTX group compared to the AZA group (5\% versus $29 \%$, respectively; $p=0.002$ ) [52]. The same patients were further followed for 60 months; improved survival was noted in the RTX group compared to AZA, $100 \%$ versus $93 \%$, respectively $(p=0.045)$. Moreover, an increased major relapse-free survival was shown in the RTX group $(49.4 \%$ versus $71.9 \%$, respectively; $p=0.003$ ) [53].

Two different regimens of RTX for maintenance therapy were compared in the MAINRITSAN-2 trial, using a fixed or individualized schedule. Participants in the fixed-dose group received RTX every 6 months, like the first MAINRITSAN study. In the individualized schedule group, participants were treated according to CD19+ B lymphocytes and ANCA titers. They received the first infusion of RTX; additional infusions were given only if CD19+ B cell counts were superior to $0 / \mathrm{mm}^{3}$, if ANCA titers increased (2-fold rise) or became positive (when previously negative), when measured every three months. A median of five and three infusions in two years were received in the fixed and the individualized schedule groups, respectively. At 28 months of follow-up, no significant difference in relapse rate was shown between treatment regimens $(9.9 \%$ for fixed schedule versus $17.3 \%$ for individualized; $p=0.22$ ) [54].

Patients from the MAINRITSAN-2 trial were subsequently enrolled in the MAINRITSAN-3 trial, if they were in remission at the end of the former study follow-up period. Long-term use of RTX was studied by giving additional $500 \mathrm{mg}$ IV RTX doses every 6 months for 2 years more versus placebo infusions; 2 versus 4 years of maintenance treatment with RTX were therefore compared. An increased relapsefree survival was associated with prolonged RTX treatment and no major relapses or rise in adverse effects was seen in this group. At 56 months, relapse-free survival rates in RTX versus placebo groups were $96 \%$ and $74 \%$, respectively $(p=0.008)$, with no difference in severe adverse effects [55].

RTX was also studied specifically for maintenance of remission in patients with GPA or MPA following a relapse. The RITAZAREM trial [NCT01697267] compared RTX (1000 mg IV every 4 months) versus AZA for maintenance therapy. At 24 months, $13 \%$ of patients receiving RTX relapsed versus $38 \%$ for patients treated with AZA (HR $0.35, p<0.001)[56]$.

In summary, at this time, RTX should be the preferred agent to maintain remission in patients with $\mathrm{AAV}$, as it was shown superior to AZA in newly diagnosed patients and those with relapsing disease [5]. In patients at higher risk of relapse, RTX should probably be continued for 4 years. Some vasculitis experts prefer initiating RTX using the fixed schedule regimen for the first 2 years and then transitioning to the individualized RTX regimen (based on ANCA and CD19+ B lymphocyte done every 3 months). More studies are needed to better individualize the treatment regimen, based on each patient and disease characteristics.

5.3. Role of Low-Dose Glucocorticoids to Prevent Relapses. The role of prolonged low-dose oral GC (prednisone $5 \mathrm{mg}$ daily for example) has largely been questioned regarding its safety and efficacy for the maintenance of remission. The Assessment of Prednisone in Remission Trial (TAPIR) [NCT01933724] is aimed at determining the rate of relapse at 6 months in patients continuing low-dose prednisone for maintenance therapy compared to its discontinuation. More precisely, participants enrolled in this study are in remission after a flare, which happened within the previous 12 months, and on daily prednisone doses of $5 \mathrm{mg}$ at randomization. Patients are then randomized to continue the same dose or to taper it down to $0 \mathrm{mg}$ within a month. The rate of relapse is then assessed at 6 months after randomization [57]. Results of this trial, still recruiting, will help to give us insight on the use of GC to maintain remission. In France, the MAINEPSAN trial enrolls GPA or MPA patients in remission with maintenance RTX regimen. The diagnosis must have been made more than 12 months prior to inclusion and patients must have received GC for 12 months before enrollment. All participants are treated with 5 to $10 \mathrm{mg}$ of daily prednisone within 35 days prior to randomization. Patients are then randomized to continue $5 \mathrm{mg}$ of daily prednisone until week 52 or to discontinue prednisone within a month, using a weekly taper of $1 \mathrm{mg}$. Relapse-free survival will be assessed at week 120 of randomization.

5.4. Other Therapies: Belimumab, Abatacept, and Trimethoprim-Sulfamethoxazole. More recently, belimumab was studied as a maintenance therapy in GPA and MPA. Belimumab is a human monoclonal $\operatorname{IgG} \lambda$ antibody against B lymphocyte stimulator (BLyS). In the Belimumab in Remission of Vasculitis (BREVAS) trial, this drug was compared to placebo for maintenance of remission in patients with newly diagnosed or relapsing severe GPA or MPA. All patients received a standard remission induction regimen, which included high-dose GC plus CYC or RTX. After remission was achieved, participants were randomized to receive either AZA combined with belimumab or AZA with placebo. At 12 months of follow-up, no difference was seen in relapse rate between the belimumab and placebo treatment arms, with a HR of $0.88(p=0.821)$. Interestingly, in the subgroup of patients who received RTX as an induction therapy, none of the patients relapsed when belimumab was administered in the maintenance therapy regimen, as opposed to patients who only received AZA [58]. As RTX is known to increase circulating BLyS levels, blockage of this stimulator by belimumab may improve disease control and prevent relapses [59]. The Rituximab and Belimumab Combination Therapy in PR3 Vasculitis (COMBIVAS) trial [NCT03967925] is currently ongoing in the United Kingdom and compares treatment regimens with RTX alone or combined with belimumab in patients with PR3-ANCA-positive AAV. Results of this trial are expected in 2023 [60].

Another drug studied in AAV treatment is abatacept. This molecule binds the CTLA4 domain linked to IgG1 and blocks the action of CD28, therefore preventing antigenpresenting cells to activate $\mathrm{T}$ cells [61]. In relapsing, nonsevere GPA, the Abatacept for the Treatment of Relapsing, Nonsevere, Granulomatosis with Polyangiitis (ABROGATE) trial [NCT02108860] is currently studying the efficacy of the 
drug to achieve GC-free remission. Results of this trial are expected in 2023.

Treatment with trimethoprim-sulfamethoxazole (TMPSMX) can be considered in a subset of patients with GPA with upper airway involvement. The use of TMP-SMX for maintenance therapy is possible, most often as an adjuvant treatment or following the many years of immunosuppression, but is limited due to the higher doses required (twice a day), frequent common side effects (nausea, fatigue, and rash), and potential increased risk of toxicity when used with methotrexate [62].

\section{Conclusion}

The treatment of GPA and MPA is rapidly evolving. As mortality and remission rates have significantly improved over the years, our attention is now focused on how to achieve rapid and sustained remission while minimizing treatment toxicity. As these diseases are heterogeneous in their presentation, further research on individualization of treatment according to disease subtype, genetic factors, and risk of relapse will be necessary to truly offer a state-of-the-art therapy.

\section{Take-Home Messages}

\subsection{Induction of Remission}

(i) First-line agents for induction of remission in severe GPA and MPA include cyclophosphamide or rituximab, along with glucocorticoids

(ii) Rapid reduction of glucocorticoids is safe and should be considered for induction of remission in severe GPA and MPA

(iii) Avacopan, if confirmed safe and cost-effective, may become an alternative to GC and lead to a GC-free regimen of $\mathrm{AAV}$

(iv) Plasma exchange is no longer routinely recommended in most patients with severe GPA and MPA; it has not been proven effective in terms of survival and reduction of ESRD risk in patients with severe disease. PLEX can still be considered in carefully selected patients in conjunction with vasculitis expert opinions

\subsection{Maintenance of Remission}

(i) Rituximab should be considered as the first-choice agent for maintenance of remission; azathioprine and methotrexate are appropriate alternatives if rituximab is unavailable or contraindicated

(ii) Longer treatment duration with rituximab for maintenance of remission reduces relapses in severe GPA and MPA, but it is unclear to date whether all patients, or only some subsets, would benefit of 4year duration of repeated, systematic RTX infusions (iii) Leflunomide and mycophenolate mofetil can be used when RTX, MTX, and AZA are contraindicated or not tolerated

(iv) The role of low-dose prednisone in maintenance of remission is not definitely demonstrated or established (ongoing studies)

\section{Data Availability}

All data presented in this review article has been published as original articles or abstracts and available online.

\section{Conflicts of Interest}

Dr. Pagnoux reports grants and personal fees from Roche, personal fees from ChemoCentryx, grants and personal fees from GSK, personal fees from Sanofi, personal fees from InflaRx $\mathrm{GmbH}$, and personal fees from AstraZeneca, outside the submitted work; Dr. Makhzoum reports personal fees from Hoffmann-La Roche, outside the submitted work. The other authors have no conflicts of interest.

\section{References}

[1] J. C. Jennette, R. J. Falk, P. A. Bacon et al., “2012 revised International Chapel Hill Consensus Conference nomenclature of vasculitides," Arthritis and Rheumatism, vol. 65, no. 1, pp. 111, 2013.

[2] F. Zarka, C. Veillette, and J.-P. Makhzoum, "A review of primary vasculitis mimickers based on the Chapel Hill Consensus classification," International Journal of Rheumatology, vol. 2020, Article ID 8392542, 2020.

[3] L. Shi, "Anti-neutrophil cytoplasmic antibody-associated vasculitis: prevalence, treatment, and outcomes," Rheumatology International, vol. 37, no. 11, pp. 1779-1788, 2017.

[4] D. Geetha and J. A. Jefferson, "ANCA-associated vasculitis: core curriculum 2020," American Journal of Kidney Diseases, vol. 75, no. 1, pp. 124-137, 2020.

[5] A. Mendel, D. Ennis, E. Go et al., "CanVasc consensus recommendations for the management of antineutrophil cytoplasm antibody-associated vasculitis: 2020 update," The Journal of Rheumatology, vol. 48, no. 4, pp. 555-566, 2021.

[6] M. Yates and R. Watts, "ANCA-associated vasculitis," Clinical medicine (London, England), vol. 17, no. 1, pp. 60-64, 2017.

[7] J. C. Jennette and P. H. Nachman, "ANCA glomerulonephritis and vasculitis," Clinical journal of the American Society of Nephrology: CJASN, vol. 12, no. 10, pp. 1680-1691, 2017.

[8] E. Garcia-Vives, A. Segarra-Medrano, F. Martinez-Valle, I. Agraz, and R. Solans-Laque, "Prevalence and risk factors for major infections in patients with antineutrophil cytoplasmic antibody-associated vasculitis: influence on the disease outcome," The Journal of Rheumatology, vol. 47, no. 3, pp. 407-414, 2020.

[9] C. Mukhtyar, L. Guillevin, M. C. Cid et al., "EULAR recommendations for the management of primary small and medium vessel vasculitis," Annals of the Rheumatic Diseases, vol. 68, no. 3, pp. 310-317, 2009.

[10] C. Mukhtyar, R. Lee, D. Brown et al., "Modification and validation of the Birmingham Vasculitis Activity Score (version 3)," 
Annals of the Rheumatic Diseases, vol. 68, no. 12, pp. 18271832, 2009.

[11] J.-P. Makhzoum and C. Pagnoux, "Current approaches for the treatment of granulomatosis with polyangiitis and microscopic polyangiitis," Revue du Rhumatisme Monographies, vol. 84, no. 3, pp. 242-248, 2017.

[12] D. Geetha, Q. Jin, J. Scott et al., "Comparisons of guidelines and recommendations on managing antineutrophil cytoplasmic antibody-associated vasculitis," Kidney International Reports, vol. 3, no. 5, pp. 1039-1049, 2018.

[13] Z. S. Wallace and E. M. Miloslavsky, "Management of ANCA associated vasculitis," BMJ, vol. 368, 2020.

[14] M. Yates, R. A. Watts, I. M. Bajema et al., "EULAR/ERAEDTA recommendations for the management of ANCAassociated vasculitis," Annals of the Rheumatic Diseases, vol. 75, no. 9, pp. 1583-1594, 2016.

[15] E. Ntatsaki, D. Carruthers, K. Chakravarty et al., "BSR and BHPR guideline for the management of adults with ANCAassociated vasculitis," Rheumatology (Oxford), vol. 53, no. 12, pp. 2306-2309, 2014.

[16] L. McGeoch, M. Twilt, L. Famorca et al., "CanVasc recommendations for the management of antineutrophil cytoplasm antibody (ANCA)-associated vasculitides - executive summary," Canadian Journal of Kidney Health and Disease, vol. 2, 2015.

[17] D. Chanouzas, J. A. G. McGregor, P. Nightingale et al., "Intravenous pulse methylprednisolone for induction of remission in severe ANCA associated vasculitis: a multi-center retrospective cohort study," BMC Nephrology, vol. 20, no. 1, p. 58, 2019.

[18] M. C. van der Goes, J. W. G. Jacobs, M. Boers et al., "Monitoring adverse events of low-dose glucocorticoid therapy: EULAR recommendations for clinical trials and daily practice," Annals of the Rheumatic Diseases, vol. 69, no. 11, pp. 1913-1919, 2010.

[19] M. Walsh, P. A. Merkel, C. A. Peh et al., "Plasma exchange and glucocorticoids in severe ANCA-associated vasculitis," New England Journal of Medicine, vol. 382, no. 7, pp. 622-631, 2020.

[20] S. P. McAdoo, N. Medjeral-Thomas, S. Gopaluni et al., "Longterm follow-up of a combined rituximab and cyclophosphamide regimen in renal anti-neutrophil cytoplasm antibody-associated vasculitis," Nephrology, Dialysis, Transplantation, vol. 34, no. 1, pp. 63-73, 2019.

[21] A. Salama, R. Pepper, S. Mcadoo, and C. Pusey, "Comment on: A novel glucocorticoid-free maintenance regimen for antineutrophil cytoplasm antibody-associated vasculitis: reply," Rheumatology, vol. 58, no. 6, p. 1119, 2019.

[22] R. J. Pepper, S. P. McAdoo, S. M. Moran et al., “A novel glucocorticoid-free maintenance regimen for anti-neutrophil cytoplasm antibody-associated vasculitis," Rheumatology, vol. 58, no. 2, pp. 260-268, 2018.

[23] A. N. T. H. O. N. Y. S. FAUCI, “Wegener's granulomatosis: prospective clinical and therapeutic experience with 85 patients for 21 years," Annals of Internal Medicine, vol. 98, no. 1, pp. $76-85,1983$.

[24] G. S. Hoffman, "Wegener granulomatosis: an analysis of 158 patients," Annals of Internal Medicine, vol. 116, no. 6, pp. 488-498, 1992.

[25] K. de Groot, L. Harper, D. R. Jayne et al., "Pulse versus daily oral cyclophosphamide for induction of remission in antineutrophil cytoplasmic antibody-associated vasculitis: a randomized trial," Annals of Internal Medicine, vol. 150, no. 10, pp. 670-680, 2009.
[26] L. Harper, M. D. Morgan, M. Walsh et al., "Pulse versus daily oral cyclophosphamide for induction of remission in ANCAassociated vasculitis: long-term follow-up," Annals of the Rheumatic Diseases, vol. 71, no. 6, pp. 955-960, 2012.

[27] A. Emadi, R. J. Jones, and R. A. Brodsky, "Cyclophosphamide and cancer: golden anniversary," Nature Reviews Clinical Oncology, vol. 6, no. 11, pp. 638-647, 2009.

[28] R. B. Jones, J. W. Cohen Tervaert, T. Hauser et al., "Rituximab versus cyclophosphamide in ANCA-associated renal vasculitis," New England Journal of Medicine, vol. 363, no. 3, pp. 211-220, 2010.

[29] J. H. Stone, P. A. Merkel, R. Spiera et al., "Rituximab versus cyclophosphamide for ANCA-associated vasculitis," New England Journal of Medicine, vol. 363, no. 3, pp. 221-232, 2010.

[30] U. Specks, P. A. Merkel, P. Seo et al., "Efficacy of remissioninduction regimens for ANCA-associated vasculitis," New England Journal of Medicine, vol. 369, no. 5, pp. 417-427, 2013.

[31] S. Unizony, M. Villarreal, E. M. Miloslavsky et al., "Clinical outcomes of treatment of anti-neutrophil cytoplasmic antibody (ANCA)-associated vasculitis based on ANCA type," Annals of the Rheumatic Diseases, vol. 75, no. 6, pp. 11661169, 2016.

[32] C. F. Valerie Benard, M. Zarandi-Nowroozi, M. Durand et al., "Comparison of two rituximab regimens for induction of remission in antineutrophil cytoplasm antibody-associated vasculitis: systematic review and meta-analysis," Arthritis Rheumatology, vol. 70, 2020.

[33] H. Xiao, P. Heeringa, P. Hu et al., "Antineutrophil cytoplasmic autoantibodies specific for myeloperoxidase cause glomerulonephritis and vasculitis in mice," The Journal of Clinical Investigation, vol. 110, no. 7, pp. 955-963, 2002.

[34] D. R. W. Jayne, G. Gaskin, N. Rasmussen et al., "Randomized trial of plasma exchange or high-dosage methylprednisolone as adjunctive therapy for severe renal vasculitis," Journal of the American Society of Nephrology, vol. 18, no. 7, pp. 21802188, 2007.

[35] G. Geri, B. Terrier, F. Heshmati et al., "Effect of plasma exchange in acute respiratory failure due to anti-neutrophil cytoplasmic antibody-associated vasculitis," Critical Care, vol. 22, no. 1, p. 328, 2018.

[36] D. Nezam, F. S. MP, A. Karras et al., "Renal histopathological classifications predict the renal outcomes of plasma exchange-treated ANCA-associated vasculitides with renal failure," Arthritis Rheumatol, vol. 71, supplement 10, 2019.

[37] D. R. W. Jayne, A. N. Bruchfeld, L. Harper et al., "Randomized trial of C5a receptor inhibitor avacopan in ANCA-associated vasculitis," Journal of the American Society of Nephrology, vol. 28, no. 9, pp. 2756-2767, 2017.

[38] P. A. Merkel, D. R. Jayne, C. Wang, J. Hillson, and P. Bekker, "Evaluation of the safety and efficacy of avacopan, a C5a receptor inhibitor, in patients with antineutrophil cytoplasmic antibody-associated vasculitis treated concomitantly with rituximab or cyclophosphamide/azathioprine: protocol for a randomized, double-blind, active-controlled, phase 3 trial," JMIR research protocols, vol. 9, no. 4, pp. e16664-e16664, 2020.

[39] D. R. W. Jayne, P. A. Merkel, T. J. Schall, and P. Bekker, "Avacopan for the treatment of ANCA-associated vasculitis," The New England Journal of Medicine, vol. 384, no. 7, pp. 599609, 2021. 
[40] K. De Groot, N. Rasmussen, P. A. Bacon et al., "Randomized trial of cyclophosphamide versus methotrexate for induction of remission in early systemic antineutrophil cytoplasmic antibody-associated vasculitis," Arthritis and Rheumatism, vol. 52, no. 8, pp. 2461-2469, 2005.

[41] A. C. Allison, "Mechanisms of action of mycophenolate mofetil," Lupus, vol. 14, Suppl 1, pp. s2-s8, 2005.

[42] R. B. Jones, T. F. Hiemstra, J. Ballarin et al., "Mycophenolate mofetil versus cyclophosphamide for remission induction in ANCA-associated vasculitis: a randomised, non-inferiority trial," Annals of the Rheumatic Diseases, vol. 78, no. 3, pp. 399-405, 2019.

[43] C. Pagnoux, A. Mahr, M. A. Hamidou et al., "Azathioprine or methotrexate maintenance for ANCA-associated vasculitis," New England Journal of Medicine, vol. 359, no. 26, pp. 27902803, 2008.

[44] X. Puéchal, C. Pagnoux, É. Perrodeau et al., "Long-term outcomes among participants in the WEGENT trial of remission-maintenance therapy for granulomatosis with polyangiitis (Wegener's) or microscopic polyangiitis," Arthritis \& Rhematology, vol. 68, no. 3, pp. 690-701, 2016.

[45] D. Jayne, N. Rasmussen, K. Andrassy et al., “A randomized trial of maintenance therapy for vasculitis associated with antineutrophil cytoplasmic autoantibodies," New England Journal of Medicine, vol. 349, no. 1, pp. 36-44, 2003.

[46] A. Karras, C. Pagnoux, M. Haubitz et al., "Randomised controlled trial of prolonged treatment in the remission phase of ANCA-associated vasculitis," Annals of the Rheumatic Diseases, vol. 76, no. 10, pp. 1662-1668, 2017.

[47] T. F. Hiemstra, M. Walsh, A. Mahr et al., "Mycophenolate mofetil vs azathioprine for remission maintenance in antineutrophil cytoplasmic antibody-associated vasculitis: a randomized controlled trial," JAMA, vol. 304, no. 21, pp. 2381-2388, 2010.

[48] I. S. Padda and A. Goyal, Leflunomide, in StatPearls, StatPearls Publishing Copyright (c) 2020, StatPearls Publishing LLC, Treasure Island (FL)., 2020.

[49] C. Metzler, N. Miehle, K. Manger et al., "Elevated relapse rate under oral methotrexate versus leflunomide for maintenance of remission in Wegener's granulomatosis," Rheumatology (Oxford), vol. 46, no. 7, pp. 1087-1091, 2007.

[50] N. Mustapha, L. Barra, S. Carette et al., "Efficacy of leflunomide in the treatment of vasculitis," Clinical and Experimental Rheumatology, 2020.

[51] G. S. Hazlewood, C. Metzler, G. A. Tomlinson et al., "Non-biologic remission maintenance therapy in adult patients with ANCA- associated vasculitis: a systematic review and network meta-analysis," Joint, Bone, Spine, vol. 81, no. 4, pp. 337-341, 2014.

[52] L. Guillevin, C. Pagnoux, A. Karras et al., "Rituximab versus azathioprine for maintenance in ANCA-associated vasculitis," The New England Journal of Medicine, vol. 371, no. 19, pp. 1771-1780, 2014.

[53] B. Terrier, C. Pagnoux, É. Perrodeau et al., "Long-term efficacy of remission-maintenance regimens for ANCA-associated vasculitides," Annals of the Rheumatic Diseases, vol. 77, no. 8, pp. 1150-1156, 2018.

[54] P. Charles, B. Terrier, É. Perrodeau et al., "Comparison of individually tailored versus fixed-schedule rituximab regimen to maintain ANCA-associated vasculitis remission: results of a multicentre, randomised controlled, phase III trial (MAIN-
RITSAN2)," Annals of the Rheumatic Diseases, vol. 77, no. 8, pp. 1143-1149, 2018.

[55] P. Charles, É. Perrodeau, M. Samson et al., "Long-term rituximab use to maintain remission of antineutrophil cytoplasmic antibody-associated vasculitis," Annals of Internal Medicine, vol. 173, no. 3, pp. 179-187, 2020.

[56] R. Smith and M. P. JD, “A randomized, controlled trial of rituximab versus azathioprine after induction of remission with rituximab for patients with ANCA-associated vasculitis and relapsing disease," Arthritis Rheumatology, vol. 71, suppl ement10, 2019.

[57] J. Krischer, P. F. Cronholm, C. Burroughs et al., "Experience with direct-to-patient recruitment for enrollment into a clinical trial in a rare disease: a web-based study," Journal of Medical Internet Research, vol. 19, no. 2, pp. e50-e50, 2017.

[58] D. Jayne, D. Blockmans, R. Luqmani et al., "Efficacy and safety of belimumab and azathioprine for maintenance of remission in antineutrophil cytoplasmic antibody-associated vasculitis: a randomized controlled study," Arthritis \& Rhematology, vol. 71, no. 6, pp. 952-963, 2019.

[59] S. M. Ansell, A. J. Novak, S. Ziesmer et al., "Serum BLyS levels increase after rituximab as initial therapy in patients with follicular grade 1 non-Hodgkin lymphoma," American Journal of Hematology, vol. 84, no. 2, pp. 71-73, 2009.

[60] M. Mcclure, "322. A randomised, double-blind, controlled, mechanistic study of rituximab and belimumab combination therapy in Pr3 ANCA-associated vasculitis (Combivas): study protocol," Rheumatology, vol. 58, Supplement_2, 2019.

[61] C. A. Langford, P. A. Monach, U. Specks et al., "An open-label trial of abatacept (CTLA4-IG) in non-severe relapsing granulomatosis with polyangiitis (Wegener's)," Annals of the Rheumatic Diseases, vol. 73, no. 7, pp. 1376-1379, 2014.

[62] C. A. Stegeman, J. W. Cohen Tervaert, P. E. de Jong, and C. G. M. Kallenberg, "Trimethoprim-sulfamethoxazole (co-trimoxazole) for the prevention of relapses of Wegener's granulomatosis," New England Journal of Medicine, vol. 335, no. 1, pp. 16-20, 1996.

[63] M. Walsh, A. Casian, O. Flossmann et al., "Long-term followup of patients with severe ANCA-associated vasculitis comparing plasma exchange to intravenous methylprednisolone treatment is unclear," Kidney International, vol. 84, no. 2, pp. 397-402, 2013. 